DOI: $10.22559 /$ folklor.341

folklor/edebiyat, cilt:24, sayı:96, 2018/4

\title{
Celia Devrim Günlerinde: İspanyol İç Savaşına Farklı Bir Bakış
}

\author{
Celia at the Revolation: \\ A Different Perspective of the Spanish Civil War
}

\author{
Maria Jesus Horta* \\ (İspanyolcadan Türkçeye çeviren: Inci Kut)
}

Öz

1928 yılında Elena Fortún Blanco y Negro dergisinin çocuk eki Gente Menuda'da, baş kahramanı Celia adında, çok soru soran ve her şeye şaşıran yedi yaşında küçük bir kız çocuğu hakkında yazılar yazmaya başlar. Bu öyküler İspanyol çocuk edebiyatının efsaneleşmiş en ünlü öykü dizisinin çekirdeğini oluşturur. Aguilar Yayınevi daha sonra bu öyküleri kitap formatında yayımlar, ancak 1936 yılında İspanya'da iç savaşın patlak vermesiyle dizinin yayımlanması durur. 1939'un başlarında Fortún, daha önce tefrika olarak yayımlanmamış olan Celia Madrecita (Küçük anne Celia)'yı dizinin ilk kitabı olarak çıkarır. Buenos Aires'teki sürgün yıllarında da bir sonraki kitabı olan Celia Devrim Günlerinde'yi yazar, ancak bu kitabın basılması 1987'yi bulur. Bu makale özellikle iç savaşa farklı bir açıdan baktığı için, bu eser üzerinde yoğunlaşmaktadır. Baş kahramanı, savaştan kaçarak ve ailesinin izinden giderek şehirden şehre dolaşan genç kız Celia olan kitapta bizzat Fortún'un yaşadıkları ve gerçek olaylar da yer alır. Birinci tekil şahsın ağzından anlatılan öykü, İspanya'daki çatışmaya oldukça tarafsız

* Doç. Dr., İstanbul Üniversitesi, Edebiyat Fakültesi, İspanyol Dili ve Edebiyatı Anabilim Dalı. hortamj@istanbul.edu.tr ORCID ID: http://orcid.org/0000-0002-4146-005X 
bir perspektif getirir, çünkü yazarın amacı, savaşan iki taraftan birini haklı çıkarmak ya da savunmaktan çok, çatışma sırasında yaşanan gerçekleri anlatmaktır.

Anahtar sözcükler: çocuk ve gençlik edebiyatı, Elena Fortún, Celia, Ispanyol iç savaşı

\begin{abstract}
In 1928 Elena Fortún began to publish some collaborations in the children's Sunday magazine Gente Menuda (Little People) in which Celia, an inquisitive and always wondering seven year-old girl, had the leading role. Those stories were the origin of one of Spanish children's literature most famous sagas. They were published later in book format by Aguilar publishing house, but the series was stopped when Spanish Civil War broke out in 1936. At the beginning of 1939 Fortún published the first book of the saga not previously serialized in newspapers: Celia, madrecita (Celia, Little Mother). In her exile in Buenos Aires she finished writing the next one: Celia en la revolución (Celia at the Revolution). However, this last book would not be published until 1987. In this paper we will focus specially in Celia at the Revolution given that the book provides us with a different vision about the Civil War. In the book Celia is a teenager who goes through different cities following her family and running from war. There are too the author's own experiences and real facts. Narrated in first person point of view, offers a quite impartial perspective of the conflict because the objective was to narrate the reality of war more than simply justify or defend any of the sides.
\end{abstract}

Keywords: children's and youth literature, Elena Fortún, Celia, Spanish civil war

1922 yılında Encarnación Aragoneses Urquijo, farklı takma adlarla birtakım gazetecilik çalışmaları yürütürken, uzun zamandan beri bastırdığı bir yeteneği gün yüzüne çıkarmış oluyordu. Yine de onun edebiyat dünyasına gerçekten adım atması, arkadaşı María de la Lejárraga'nın' ${ }^{1}$ 1928'in başlarında onu $A B C$ gazetesinin genel müdürüne tanıtmasıyla başlar. (Dorao, 1999, s. 81). Ad1 geçen gazeteye ait haftalık Blanco y Negro dergisinin çocuk eki olan Gente Menuda (Küçük insanlar)'da, Elena Fortún takma adı altında, özgün hikâyelerden masallara ya da ünlü tablolar ve icatlar üzerine yorumlara varana kadar yazılar yayınlar. Bu yazıların hepsinde, büyüklerin dünyasının ve kurallarının küçükler için ne kadar mantıksız olduğunu göstermeye çalışırken, çocukların dünyasına gerçekten bir çocuğun gözüyle bakarak yaklaşmaya çalışması, onun en önemli özelliğini oluşturuyordu. Bunu başarabilmek için kendi kişisel deneyimlerinden olduğu kadar, Retiro Parkında çocukları gözlemler ve dinlerken aldığı notlardan, ayrıca arkadaşlarının kendisine anlattığı anekdotlardan da yararlanır (Martín Gaite, 1992, s. 29-32; Bravo-Villasante, 1986, s. 9).

24 Haziran 1928'de Gente Menuda'da diyalog biçiminde ve Santiago Regidor ${ }^{2}$ tarafından resimlendirilmiş Celia dice a su madre (Celia annesine diyor ki) başlıkl1 küçük bir öykü çıktı. Bu öykü ve aylar boyunca onu izleyen daha başka öyküler (yıl sonunda sayıları toplam on dokuzu bulmuştu), baş kahramanı Celia'nın çevresinde giderek özel bir atmosfer yaratmakta olan birtakım küçük maceralar geliştiriyordu (García Padrino, 
1968, s. 36). Bu öykülerin hepsi, İspanya'da en çok okunan ve ünü kuşaklar boyunca devam eden çocuk öykülerinden birinin kaynă̆ını oluşturacaktı. 1929'un Ocak ayına gelindiğinde, Madrid'te burjuva bir aileden gelen, sürekli soru soran ve her şeye şaşkın gözlerle bakan, yedi yaşında sarışın kız çocuğu Celia karakteri, (Martín Gaite, 1993, s. 8), derginin değişmez bir bölümünü oluşturmuş ve önemli bir ilgi merkezi haline gelmişti. Daha başından itibaren, dizinin çocuk dünyasıyla tam bir özdeşleşme içinde olmasının yanı sıra, eriştiği başarılardan biri de, içindeki ikincil karakterlerin bolluğu oldu. Bu kişiler 20'li ve 30'lu yıllardaki Madrid'le ilgili son derece isabetli bir imaj yaratmaya yaradılar (Bravo-Villasante, 1986, s. 12), zira yalnızca Celia'nın ailesinin ait olduğu orta-üst sınıf burjuva tipleri değil, dizinin büyükler arasında da popüler olmasına yarayan bir etken olarak kapıcılar, hizmetçiler, öğretmenler, arabacılar, terziler v.b. de kitaplarda yer almaktaydılar.

Kısa zamanda elde edilen bu başarı üzerine yayımcı Aguilar, kataloglarına "Lecturas Juveniles" (Gençlik kitapları) başlığı altında çocuk edebiyatına adanmış yeni bir bölüm koyarak, dergide her hafta çıkan çocuk öykülerini bir araya getirip farklı kitaplara dönüştürmek üzere yazarla bir sözleşme yaptı (Blas, 2013). İşte böylelikle 1933 yıllnda, Celia, Lo Que Dice (Celia'nın söyledikleri) ile başlamak üzere dizinin farklı kitapları gün yüzüne çıkmaya başladı. Yayımcı daha sonra aynı karakter için özel bir dizi yarattı ("Celia y su Mundo" [Celia ve Dünyas1]). Ayrica Fortún'un Teatro Para Niños (doce comedias) (Çocuklar için tiyatro. On iki komedi) (1935) ve El Bazar De Todas Las Cosas (Her Şey Pazarı) (1935) gibi çocuklara yönelik daha başka eserlerini ve María Rodrigo'yla birlikte yazdıkları Canciones Infantiles (Çocuk Şarkıları) (1934) başlıklı bir geleneksel çocuk şarkıları derlemesi yayımladı. O sıralarda Fortún, Residencia de Señoritas'ta ${ }^{3}$ Kütüphanecilik öğrenimi görüyor ve aynı yerde çocuk hikâyeleri dersleri veriyordu (Trapiello, 2016, s. 11; Fortún, 1946, s. 22).

1936 yazında, patlak veren İspanyol iç savaş yüzünden Fortún'un Gente menuda'yla çalışmaları kesintiye uğradı. Bunun üzerine bazı gazeteler için muhabir olarak çalışmaya başladı. Toplumun en küçük bireylerine karşı duyduğu ilgi, yazılarını onların üzerine odaklamasına yol açıyordu: bu masum küçük kurbanlardan, çatışmalar sırasında onların durumundan, çektikleri acılardan, ailelerini kaybettiklerinde ve yiyecek bulamadıklarında onları barındıran yurtlardan, şehirlerden tahliye edilmelerinden (Antón ve Molero 2012, s. 6) ve savaşın onları nasıl zamanından önce yetişkin insanlara dönüştürdüğünden söz ediyordu. Bu fikirlerin pek çoğu sonradan Celia en la Revolución (Celia devrim günlerinde)'nin içinde yer alacaktı.

Savaşin başından itibaren Cumhuriyetçilerin bölgesinde (Madrid, Albacete, Barcelona ve Valencia arasında) kalan yazar, 1938 yılında ciddi ekonomik sorunlar yaşamaya başlamıştı. Bunun üzerine yayımcı Aguilar'a başvurarak aynı öykülere devam etmeyi önerdi. Böylece 1939 yılı başlarında Celia Madrecita (Küçük anne Celia), doğrudan doğruya kitap formatında çıkan dizinin ilk eseri oldu. O zamanlar Fortún'un ailesi, Franco birlikleri tarafından tecrit edilmiş bir halde Barcelona'da kalmıştı. Ordudan emekli olmuş bir subayken savaş başlayınca Cumhuriyetçi orduya katılan kocası ile oğlu, galiplerin misillemelerinden korktukları için kısa bir süre sonra sınırı aşarak Fransa'ya 
geçeceklerdi. Yazar kendi geleceğinden korkmuyordu, ama aynı sürgün yolunu izlemeyi yakınları açısından bir görev olarak gördü, onun bu kararı daha sonra eserlerine de yansıyacaktı (Trapiello, 2016, s. 12). Böylelikle Madrid'ten Valencia'ya geçerek oradan Fransa'ya gidecek bir gemiye bindi. Daha sonra hepsi birlikte İsviçre'ye gittiler, en sonunda da Güney Amerika'ya göç ettiler.

Fortún, kocasıyla birlikte Buenos Aires'e yerleştikten sonra, Crítica gazetesine yazı yazmaya başladı; 1945 'ten itibaren de, yine çocuklar için önemli işler başaracağı Şehir Kütüphanesinde çalışacaktı (Antón ve Molero, 2012, s. 7). O tarihlerde yayımcı Aguilar Arjantin'de bir şube açmış, bu da aynı diziyi daha da büyük bir kolaylıkla yeniden ele almalarına olanak sağlamıştı, çünkü Elena Fortún'un sürgünde olması bile dizinin popülaritesini sona erdirebilmiş değildi. Daha önce yayımlanmış olan kitaplar 1944'ten itibaren yeniden basılmaya başlandı ve ayn yıl Celia Institutriz en América (Celia Güney Amerika'da mürebbiye) başlıklı yeni bir kitap çıktı; bunu daha başkaları izleyecek ve Franco rejimindeki sansürle aralarında çıkan bazı sorunlara rağmen 1952'de kitapların sayısı toplam yirmiye ulaşacaktı. ${ }^{4}$

Kitaplarının sürekli bir başarı elde etmesi üzerine Fortún 1948'de İspanya'ya geri dönmeye cesaret etti ve orada kocası için af çıkarmayı başardı. Ancak ülkedeki kapalı atmosfer, dostlarının pek çoğunun orada olmaması ve kocasının intiharı onun Arjantin'e geri dönmesine yol açtı. Orada yazılarına devam eden Fortún'un artık çok hasta olarak İspanya'ya kesin dönüşü 1950 yılında gerçekleşti. Barcelona'ya yerleştikten sonra 1952 yılında Madrid'te hayatını kaybetti.

Fortún'un efsaneleşmiş öykülerinin son kitabı olan Celia Devrim Günlerinde ancak yazarın ölümünden otuz beş yıl sonra, 1987'de çıkabildi. Yazar iç savaş yılları boyunca bu kitabı kaleme almak üzere notlar almış olmasına rağmen, müsveddeyi ancak Arjantin'e yerleşmesinden kısa bir süre sonra 1943'te tamamlayabildi. Yine de eserin tam bir revizyonunu yapmayı hiçbir zaman başaramadı ve İspanya'ya dönerken kitabın müsveddesini daha başka belgelerle birlikte Güney Amerika'da bırakmaya karar verdi. Celia dizisinin İspanya'da düzenli olarak yayımlanmasına ve getirdiği büyük başarıya bakılırsa, yazarın arkasında bıraktığı bu müsveddeyi geri alma konusunda herhangi bir çaba göstermemiş olması, kitabı yayımlamayı düşünmediğini aklımıza getiriyor. Müsvedde böylelikle unutulup gitti ve ancak Cádiz Üniversitesinden Prof. Marisol Dorao'nun çabaları sayesinde geri alınabildi. Fortún'un oğlunun ABD'deki dul eşini ziyarete giden Dorao, birçok müsveddeyi yayımlanmak şartıyla ondan teslim aldı. Bunların arasında Celia Devrim Günlerinde'nin özgün metni de bulunuyordu; kurşun kalemle yazılıp üzerinde pekçok düzeltmeler yapılmış olan metnin bazı bölümleri tam olarak bitirilmemiş̧i (Dorao, 1987, s. 1). Dorao ve Aguilar'ın editörleri María Puncel ve Miguel Azaola (Dorao, 1999: 9), bu müsvedde üzerinde çalışarak metni uyumlu ve tutarlı bir hale getirdikten sonra Asun Balzola'nın resimlemeleriyle 1987'de yayımladılar (Belmonde, 2013, s. 125).

Kitapta ilk önce dikkati çeken şeylerden biri başlıktır. Yazarın "savaş" ya da "iç savaş" değil de "devrim" demesi günümüzdeki okuyucuya garip gelebilir. Ancak XX. yüzyılın ilk yarısında "devrim" sözcüğü çok kullanılıyordu (Marina ve Rodríguez de 
Castro, 2009, s. 117-118) ve çok farklı bağlamlarda yer alıyordu. Yalnızca Marksist ya da komünist tarzdaki sol devrimlerden söz edilirken kullanılıyor değildi; bazen tümüyle ters anlamda ve faşist bir hareket kastediliyordu, ama barışçıl bir şekilde yürütülen topyekûn bir yenilenme hareketine de sıklıkla atıfta bulunuyordu. İspanya'da bu terim 1898'den itibaren ssrarla kullanılır olmuştu; İspanya'nın denizaşırı topraklardaki son sömürgelerini kaybetmesiyle, ülke içinde var olan siyasi sistemin artık sona erdirilmesi gereği tartışılıyor ve her açıdan tam bir yenileşme hareketinin gerçekleştirilmesi isteniyordu.

Ancak 1936 yılında iç savaşın patlak vermesiyle "devrim" kelimesi yeni bir boyut kazandı. Çatışmanın ilk ayları boyunca, Cumhuriyetçi kesimden savaşanların pek çoğu, Cumhuriyet'i savunma uğruna mücadele etmekten çok, İspanya'yı yeniden şekillendirecek Marksist-komünist bir "devrim"i gerçekleştirmek için çaba harcadılar. Pek çok bölgede, hükümet kararsız kalıp tepki göstermekte gecikirken, 17 Temmuz darbesinin başarıya ulaşmamasını sağlayanlar, farklı enternasyonalist partilere ait işçiler ve sendikacılar tarafından örgütlenmiş milisler oldu. Ama darbenin iç savaşa yol açtığ 1 açıklı kazanıp sıra devletin savunulmasını örgütlemeye geldiğinde, milisler temel amaçlarının kapitalist sisteme karşı savaşmak ve "devrimci bir savaşı" gerçekleştirmek olduğunu açıklayarak hükümetin denetimi altına girmeye yanaşmadılar. Aslında bu durum, Cumhuriyetçi kuvvetlerin birleştirilmesinin önündeki en büyük engellerden birini ve sonunda yenilgiye uğramalarının da ana nedenlerinden birini oluşturdu, çünkü milisler darbeyi durdurmakta yeterli olmuşlardı ama (yeterli eğitim, disiplin ve silahlardan yoksun olduklarından) savaşı kazanacak kapasiteye sahip değillerdi.

Yine de "devrim" kelimesi isyancılar tarafindan da kullanıliyordu ve onlar, bir noktaya kadar Alman nasyonal-sosyalist partisinin yolunu izleyerek, başlattıkları ayaklanmaya "ulusal-sendikalist devrim" adını vermişlerdi (Trapiello, 2016, s. 14-15). Aynı terim, Franco diktatörlüğünün ilk yıllarından, İspanya'da aynı general tarafından gerçekleştirilen “devrim”"iyüceltmek amaciyla da kullanılır olmuştu(Marina ve Rodríguez de Castro, 2009, s. 118). Böylelikle İspanya'daki iç savaş, birbirine zıt ideolojilerdeki iki ayrı tip devrim arasında yürütülmüş bir çatışma şeklinde yorumlanabilir. Bu nedenle "devrim" terimi savaş sırasında yazılan eserlerde sıklıkla karşımıza çıkmaktadır.

Aslında söz konusu kitapta bu terimin her iki tarafa da atıfta bulunduğunu görüyoruz. Romanın başında, Celia'yla kız kardeşleri Segovia'dan ayrılırlarken karşılaştıkları köylü kadınlar, isyancıları kastederek, şehirde "devrim" olup olmadığını sorarlar (Fortún, 1987, s. 28). Madrid'e vardıklarındaysa, yanlarındaki hizmetçi kadın Valeriana, orada gerçekten "devrim" yapıldığı kanısındadır, çünkü ortalıktaki herkes işçilere benzemekte, sloganlar atmakta ve birbirleriyle senli benli konuşmaktadırlar (Fortún, 1987, s. 34).

Daha ilk baştan itibaren kitapta dikkati çeken ikinci özellik, baş kahramanın uğradığ dönüşüm ve eserin üslubundaki değişimdir. Birincisi, Celia artık bir kız çocuğu değildir: savaş başladığında on altı yaşındayken kitabın sonunda on dokuz yaşındadır (Fortún, 1987, s. 290). Hattâ birkaç yaş da büyük göstermektedir, hattâ bu yüzden Madrid'i Tahliye Komitesi sorumlularından biri, kızın kimlik kartında yaşını yirmiiki ${ }^{5}$ olarak göstermeye, ayrıca yetişkin olduğunu yazmaya karar verir. Böylelikle tek başına yolculuk edebilecek 
ve yaşayabilecek, ayrıca gerektiğinde kız kardeşlerine vasilik edebilecektir (Fortún, 1987, s. 126 ve 258). Kitaptaki en çocukça unsur, küçük kız kardeşlerinin (1936'da biri altı, öteki iki yaşındadır) ve Madrid’teki yurtta kalan öteki çocukların kitabın yalnızca ilk bölümlerinde görünmeleri, bu da gösteriyor ki kitap henüz daha küçük yaştaki çocuklara odaklanmamıştır, belki de bunun nedeni savaş gerçeğinin çocukların dünyasıyla karıştırılamayacak kadar acımasız olmasıdır. Celia Devrim Günlerinde'nin merkezinde, yeniyetme başkahraman, onun gündelik yaşantısı, sıkıntıları, korkuları ve savaş nedeniyle durmadan oradan oraya taşınması yer almaktadır. Ayrıca olaylar birinci tekil şahıs olarak onun ağzından anlatılmakta ve anlatının içine sıklıkla macera ve romantik roman öğeleri katılmaktadır.

Bu noktada anımsatılmalıdır ki, bir önceki kitap olan Küçük Anne Celia'da (1939) baş kahramanın nasıl bir dönüşüm geçirdiği bilinmeden, Celia Devrim Günlerinde'de olanlar okuyucuya pek de inanılır gelmeyecektir. Küçük Anne Celia, dizinin daha önceki kitaplarıyla kıyaslandığında besbelli bir dönüşüm geçirmiştir. O zamana kadar Celia Gálvez, genç, zengin ve modern ana babaya sahip, ilk başlarda İngiliz mürebbiyesi olan ve daha sonra Fransız rahibelerin okuluna giden (zaten bu yüzden İspanyolcanın dışında akıcı bir şekilde İngilizce ve Fransızca konuşan), zeki ve yaramaz bir kız çocuğu olarak görünmektedir, bir evleri Madrid'te, bir evleri Madrid'ten $60 \mathrm{~km}$ kadar uzaktaki dağdadır, yaz tatillerini San Sebastián'da, Santander'de ve Côte d'Azur'de geçirmektedirler, kızın çevresi her zaman oyuncaklarla, pahalı ve zevkli giysilerle doludur (Dorao, 1990, s. 23). Celia büyümeye başladığında, küçük kızın dünyası bir grup kardeşler, arkadaşlar ve kuzenler tarafından istilaya uğrar; bunlar dizinin o çocukça atmosferini sürdürmeye yarar. Oysa Kü̧̈ük Anne Celia'da içinde yaşadıkları çevre ve karakterlerin koşulları değişmiştir; Celia yeniden romanın merkez noktasını oluşturur. Aynı zamanda anlatının üslubunda da bir değişim gerçekleşir (García Padrino, 1986, s. 50). Artık o zaman Celia on dört yaşında bir genç kıza dönüşmüştür, ailenin ekonomik çöküntü içinde olması nedeniyle ve annesinin beklenmedik ölümünün ardından Madrid’teki eğitimini bırakmak zorunda kaldığ 1 gibi, aynı zamanda büyükbabasının Segovia'daki evinde iki küçük kız kardeşinin bakımını üstlenmek üzere, içinde yeni yeni uyanmakta olan çocuk masalları yazma hevesini de bir yana bırakması gerekmiştir (onun bu eğilimi bizzat Elena Fortún'un kitaba yansımasıdır; Fortún, 1939, s. 2). Yaşam biçimini altüst eden bu ani darbe Celia'da kaçınılmaz bir hayal kırıklığ 1 yaratmıştır ve savaş patlak verdiğinde bunun üstesinden hâlâ gelebilmiş değildir. Bu durum öyküler dizisindeki değişimin de başlangıcını oluşturur, artık o noktadan sonra yalnızca en küçüklere ve onların dünyasına odaklanmayı bırakmıştır. Belki de Kuçük Anne Celia İspanyol iç savaşının son demlerinde Fortún için son derece kişisel ve güvensiz koşullar altında yazılmış olduğundan kitaptaki tezin gelişimini etkileyebilmiştir. Ama hiç kuşku yok ki Gálvez ailesinin parasal sıkıntıları ve Celia'nın kız kardeşlerine annelik etme zorunda kalarak yetişkin insanların dünyasına girmesi onun için gerçek bir "okul" olacak ve bu sayede savaş sırasında daha kolaylıkla hayatta kalabilecektir.

Bu durum ve öykünün bu iki kitap arasında fazla bir değişiklik göstermeden devam etmesi ${ }^{6}$, arkasından da Celia Güney Amerika'da Mürebbiye (1944) başlığını taşıyan 
bir sonraki kitapta da sürüp gitmesi, Fortún'un bir an gelip bu üç kitaptan oluşan bir tür üçleme yazmayı düşündüğünü akla getirmektedir. $\mathrm{Bu}$ üç öykü arasında çok yakın bir ilişki vardır ve bunlardaki olaylar boyunca kahramanın, kaygısız bir yeniyetmeden, kaderin sillesini yiyip korkunç gerçekler karşısında olgunlaşmak zorunda kalmış genç bir kıza dönüşürken geçirdiği evrim tüm çıplaklığıyla görülebilmektedir. Bu anlamda bu üç kitap tefrika halinde çıkmış bir Bildungsroman oluştururken, asıl amacı İspanyol iç savaşından önce, savaş sırasında ve savaşın ardından yaşanan koşulların resmini çizmek olmuştur ${ }^{7}$. Ancak bu varsayımsal üçleme, ikinci kitabın zamanında yayımlanmamasıyla eksik kalmıştır.

Elena Fortún, Buenos Aires’te verdiği bir konferansta, başımıza gelen bir şeyi anlatmamızın üç nedeni olduğunu söylemiştir: olanları başkalarına anlatma arzusu (çünkü olaylar o kadar önemlidir ki başkalarına anlatmadan yapamayız), olan biteni hatırlama ve bunları anlatmakla başımıza gelenleri aynı yoğunlukta bir kez daha yaşamamız (Fortún, 1946, s. 25). İşte Fortún'u Celia Devrim Günlerinde'yi yazmaya iten de bu anlatma gereksinimi olmuştur ve bu kitabın yazılması onun savaş boyunca yaşanmış her şeyden arınmasını sağlayacak bir tür katarsis olabilir (Sotomayor, 2008, s. 272). Belki de bu yüzden bu kitabı hiçbir zaman yayımlamama kararını almıştır. Carmen Martín Gaite, bu kitabın "savaşta yaşanan korkunç şeylerin tüyler ürpertici bir tanığı olduğu ve bunları yazmakla yazarın kendi yaşadıklarına vücut verdiğì" kanısındadır (1993, s. 36). Ayrıca kitabın asıl kahramanının Celia olmadığını, hattâ bizzat Fortún'un bile değil de "savaş"ın baş kahraman olduğunu ekler. Çünkü Celia Devrim Günlerinde öyküsünde, o sıralar İspanya'da yaşanmakta olan ciddi sosyo-politik durumla ilgili hatırlatmalar anlatının içine serpiştirilmiş sıradan unsurlar değil, kitabın bileşiminde sürekli olarak var olan bir ana maddedir. Celia, halkın büyük bir çoğunluğu gibi hayatını sürdürmeye çabalarken, olan biten her şeyin tanı̆̆ 1 olmaktadır.

Bu kitapta Gálvez ailesinin savaş boyunca yaşadığı iniş çıkışlar görülür. Birincisi, Celia ile iki kız kardeşi, Segovia'da isyancılar galip gelince, geceleyin gizlice şehirden kaçmak zorunda kalırlar; bu sırada onlara büyükbabalarının yanında çalışan bazı hizmetkârlar yardım edecektir; emekli bir general olan ve Cumhuriyetçilere yardım eden büyükbaba sonradan tutuklanacak ve kurşuna dizilecektir (Fortún, 1987, s. 14-34). Babalarıyla buluşmak üzere Madrid'e vardıklarında onun da askere yazıldığını öğrenirler ve halaları Julia'nın yanına sığınırlar. Yalnızca bir buçuk yıl önce ayrılmış olduğu başkent, Celia için tanınmayacak haldedir: her taraf bakımsız ve kirlidir, toz toprak içinde ve hurdalarla doludur. Erkekler cephede ya da milislerle birlikte olduklarından çalışacak kimse yoktur, sokaklarda ve tramvaylarda kontrol noktaları vardır, pek çok aile şehirden çekip gitmiştir, pek çokları da sığınmacı olarak gelmektedir. Ama Celia'ya en çarpıcı gelen şey, herkesin proleterler gibi giyinmiş olması ve öyle davranmasıdır (Fortún, 1987, s. 32-36, 44, 126), bu da "devrim"in yürümekte olduğunun bir göstergesidir (ama garip bir devrimdir bu, çünkü sokaklarda kalabalıklar, hatipler ya da bayraklar değil, savunma durumunda insanlar vardır [Fortún, 1987, s. 39]). O arada orta ya da üst sinıftan insanlar burjuva görünümlerini belli etmemeye çalışmaktadırlar, çünkü Franco taraftarlarını desteklemekle suçlanarak tutuklanmaktan ya da öldürülmekten korkmaktadırlar. 
Celia'nın Falange Española Partisine (İspanyol Falanj, o dönemdeki faşist partilerden biridir) üye olan kuzeni Gerardo saklanmaktadır ve kısa bir süre sonra evdeki hizmetçi tarafından ihbar edilerek bir paseo ("gezinti") 8 sırasında öldürülecektir (Fortún, 1987, s. 38, 54-58). Halas1 da ortadan kaybolacaktır; büyük bir olasılıkla, Celia onu engelleyecek bir şey yapamadan, oğlunun cesedini teşhis etmeye giderken öldürülmüştür (Fortún, 1987, s. 59-60). O arada babası da cephede aldığı yaralar yüzünden ağır yaralı olarak hastanede yatmaktadır. Bunun üzerine Celia, kız kardeşleri ve büyükbabasının hizmetçisi Valeriana, babaları taburcu olana ve şehrin varoşlarındaki Chamartín'de bulunan evlerinde bir araya gelebilene kadar Serrano caddesindeki bir çocuk yurduna yerleşirler. O zamanlar başkentteki pek çok mahalle bombardımana uğramış, boşaltılmış ve yağmalanmıştır, kısa bir süre sonra onlar da sürekli bombardımana uğrayacaklar ve şehrin başka bölgelerinden gelip sığınmış aileleri evlerine almak zorunda kalacaklardır (Fortún, 1987, s. 87-88). Madrid kuşatması daraldıkça, yiyecek bulma sorunu kritik bir hal almaya başlar. Bunun üzerine küçük çocuklarla Valeriana, Valencia'daki başka bir yurda gönderilirler; hükümetin de taşınmış olduğu bu şehir o zamanlar sakin bir bölgedir (Fortún, 1987, s. 87-91).

Kısa bir süre sonra çatışmalar yoğunlaşır, isyancılar şehrin kapılarındadır, babası yeniden cepheye çağrılınca Celia evi Talaveralı bir sığınmacıya emanet ederek kız kardeşlerinin yanına gitmeye karar verir. Ancak Valencia'ya vardığında yurt taşınmıştır ve kızların nerede olduğunu kimse bilmemektedir. Kardeşlerini aramak için Albacete'ye kısa bir yolculuk yaptıktan sonra onlardan haber almak ümidiyle yeniden Valencia'ya döner. Orada 1936 ilkbaharında Santander'de tanımış olduğu ve şimdi asker olan Jorge'yle karşılaşır; açlığa, bombardımanlara ve kötü haberlere rağmen hayatta kalmaya çalışırlarken onunla masum bir aşk macerası yaşar. 1937'de Celia, kız kardeşlerinin izini sürmek için, hükümetin de yaptığı gibi Barcelona'ya taşınır ve bu kez oraya atanmış olan babasıyla buluşur. Ancak 1938'in ortalarında Barcelona'da hedef gözetmeyen yoğun bombardımanlardan kaçmak için Madrid'e geri döner. Orada dramatik birkaç ay geçirecektir, çünkü başkent artık ağır saldırıların hedefi olmamakla birlikte, yiyecek sorunu şehir sakinleri için gerçek bir işkenceye dönüşmüştür. Bu noktadan itibaren savaşın sonuyla ilgili yorumlar kitapta bol bol yer alır ve kızın görüşü giderek daha da kötümser bir hal alır, çünkü savaş kaybedilmiştir. 1939'un başlarında Celia'nın kuşkuları artmıştır: Barcelona düşmüştür (Fortún, 1987, s. 254) ve babasının Fransa sınırını geçerek kaçıp kaçamadığını bilememektedir. Sevgilisi Jorge'ye gelince, onun birliği Aragón cephesinde kaybolduğu ve hepsine öldü gözüyle bakıldığı halde, Celia buna inanmay1 reddeder (Fortún, 1987, s. 256). Bir tek, 1937'den beri Valeriana'yla birlikte Fransa'da bulunan kardeşlerinin durumu onu teselli etmektedir (Fortún, 1987, s. 173 ve 178$)$.

20 Şubat 1939'dan itibaren kitap bir tür günlüğe dönüşür ve on beş gün boyunca Celia Cumhuriyet'in kesin olarak yıkılmasına tanık olurken, hayatının en önemli kararlarından birini almak zorunda kalır: galiplerin misillemelerinden etkilenmeyeceğine güvenerek ama ne zaman yurt dışına çıkabileceğini bilmeden ailesinden uzak olarak İspanya'da kalma veya hak etmediğini düşündügü belirsiz bir sürgün hayatı içinde yakınlarını 
aramak üzere ülkeden ayrılma kararıdır bu. Arkadaşları ve tanıdıkları kalması için onu ikna etmeye çalışırlar, ama sonunda ailesine karşı olan görevi baskın çıkar. 1939'un 1 Mart günü yeniden Valencia'ya gider ve orada olayların hızla gelişmesine tanık olur: pek çok kişi açık ya da kapalı bir şekilde galiplerin tarafından olduklarını çoktan ilan etmişlerdir ve hiç kimse mağluplarla ilişkili olmak istememektedir. Ayın 18'inde (tıpkı Fortún'un da aynı gün yaptığı gibi) sürgüne gitmek üzere, yanında pek az eşyayla, (bir arkadaşının usulca verdiği bir kitabın içinde saklı birkaç kâğıt paranın dışında) hiç parası ya da değerli bir şeyi olmadan, babası ve kardeşleriyle buluşup buluşamayacağını da bilemeden, tek başına bir İngiliz yük gemisine biner.

Celia'nın başından geçen maceralar, bizzat Fortún'un savaş boyunca yaşadığı yer değiştirmelerle genel hatlarıyla örtüşmekte (Sotomayor, 2008, s. 274-275) ve kurgusal öğelerle harmanlanmış oldukları halde yazarın içinde bulunduğu kişisel koşulları yansitmaktadır (García Padrino, 1986, s. 34). Bu maceralar aynı zamanda bizlere çatışmanın geçirdiği evrime oldukça yakın bir görüntü vermeye de yaramaktadır (Franco, 2013, s. 70). İlk önce, hükümete karşı yapılan darbenin kısmi bir zafer kazanması. Sonra 1936'nın sonbaharı boyunca Madrid'in kuşatılmasının ve hükümetin devrimci milisleri bastırma çabasının yanı sıra şehre boyun eğdirme amacındaki Franco birliklerinin bombardımanları. Onun arkasından Cumhuriyetçi hükümetin Valencia'ya taşınması ve son derece vahim yiyecek sorunları. Daha sonra Cumhuriyetçilerin son bir taarruzu, toplumsal kaosun artması ve savaşın kaybedilmekte olduğu belli oldukça uğranılan moral kaybı. 1939'un başlarında Barcelona'nın kuşatılması ve Fransa sınırına doğru bir göçün başlaması. Ve son olarak Franco'nun artık kesin olan zaferinin ardından bazı kimselerin herhangi bir yerden yurt dışına kaçma çabaları ve Frankistlerin misillemeleri; en sonunda da pek çok kişinin ani olarak saf değiştirmesi.

Kitabın ilk bölümlerinde, hem Celia'nın hem de başka kişilerin (örneğin Valeriana'nın ya da Chamartín'deki evin bahçıvanının) neler olup bittiğini (Fortún, 1987, s. 38), arkadaşlarının artık kimler olduklarını (Fortú 1987, s. 24), kimin haklı kimin haksız olduğunu (Fortún, 1987, s. 33, 35 ve 116) merak etmelerini gözlemlemek son derece ilginçtir. Celia kendini Cumhuriyetçi dünyaya bağlı hissetmektedir, ama babasıyla sevgilisi Cumhuriyetçiler uğruna savaştıkları ve büyükbabası onları savunurken öldüğü halde, hiçbir zaman Cumhuriyetçi davaya övgüler dizmediği gibi o kesim içindeki farklı ideolojilerin herhangi birini savunmaya da kalkmaz. Aslında Celia kendini herkese ve her şeye yabancı hissetmektedir, neler olduğunu anlamaya çalışır ama başaramaz. Büyükbabasının öldürülmesi onu son derece nazik bir noktada öylesine gafil avlamışıtır ki (Fortún, 1987, s. 31) sanki hiçbir tepki veremez. Öte yandan kuzeninin ve halasının ölümleri onu son derece etkiler. Ama tanımadığı kişilerin her günkü ölümleri, kurşuna dizilmeler ve her gün tekrarlanan, hattâ onları engelleyecek hiçbir şey yapamadan gözlerinin önünde gerçekleşen "gezintiler", checa $a^{9}$ denilen olağanüstü komitelerin yaptıkları hakkındaki yorumlar (Fortún, 1987, s. 61), sokaklarda her yanda görülen cesetler... Özellikle de insanların bu olgular karşısında gösterdiği tepkiler: idam mangalarına bağırıp çağırmalar, ölülere ya da idama götürülenlere yağdırılan hakaretler, komşularını ihbar eden her türlü insan, bölünen aileler ya da karşı karşıya gelen aile 
bireyleri, şantajlar... Gerçi aynı derecede doğru olan bir şey varsa o da pek çoklarının olayları ne gördükleri ne duydukları, ne bir yorumda bulundukları ne de bilmek istedikleriydi.

Celia küçükken yetişkinlerin dünyası ona nasıl saçma görünüyor idiyse, şimdi de savaş ona öyle görünmektedir: saçma ve kanlı. Ama bunu pek az kişiyle konuşabilmektedir. Babası gerçekleri görmek istemez, eğer birini kurşuna diziyorlarsa "hainleri desteklemiştir de ondan" (Fortún, 1987: 50). Daha sonra da adaletin Cumhuriyetçilerden yana olduğuna ve savaşı kazandıklarında çarpıklıkların ortaya çıkacağına onu inandırmaya çalışacaktır. Sevgilisi acımasız gerçeği kabul eder ve kendisi de dâhil herkesin birer caniye dönüştüğünü itiraf eder (Fortún, 1987, s.132); İspanyol iç savaşıyla ilgili hiçbir romanda görülmemiş bir itiraftır bu. Aslında kitaptaki pek çok küçük hikâye, Fortún'un çatışmalar sırasında farklı gazetelere yazdığ 1 türden haberleri andırmaktadır ve bizlere savaşın gaddarlığını göstermektedir. Örneğin Talaveralı sığınmacılardan bir kadın, kendilerini kasabayı boşaltmak zorunda bıraktıklarında tarlada çalışmakta olduğundan yeni doğmuş çocuğunu nasıl yanına alamadığını ve Madrid'e giderlerken, sivil halktan olduklarını bile bile onları yolda nasıl acımasızca bombaladıklarını anlatır (Fortún 1987, s.89-91). Bir başka yerde, başkentte çocukların sanki masum bir şeymiş gibi kurşuna dizme oyunları oynadıklarını görürüz (Fortún, 1987, s. 69). Daha başkaları ağaçtan sallanan bir el ya da bir odanın duvarına olduğu gibi yapışmış insan beyni gördüklerini anlatırlar (Fortún, 1987, s.208). Jorge "Jaén treni katliamı" $11^{10}$ nakleder (Fortún, 1987, s.152) ve Celia babasının yattığı hastanede General López Ochoa'nın ${ }^{11}$ zincirden boşanmış bir güruhun elinde katledilmesine tanık olur (Fortún, 1987, s. 52-53). Kitapta ortaya çıkan tek gerçek kişi o değildir: aynı şekilde Isabel García Lorca ${ }^{12}$ ve Laurita de Los Ríos'a ${ }^{13}$ (Fortún, 1987, s .80-81) ya da Manuel Aguilar'ın ${ }^{14}$ ta kendisine ve eşi Rebeca'ya da rastlarız (Fortún, 1987, s. 244, 253 ve 260). Ayrica Ramiro de Maeztu ve Muñoz Seca ${ }^{15}$ gibi yazarların San Antón hapishanesinde nasıl tutuldukları da anlatılır (Fortún, 1987, s. 81). Öte yandan, örneğin Celia'nın sıklıkla Elena Fortún'un kocasıyla özdeşleştirilen babası gibi bazı şahıslar pek çok bakımdan gerçek kişilerin kopyalarıdır.

Yine de bütün bu korkunç şeylerin yanı sıra kitapta, tansiyonu düşürmeyi başaran, masum hattâ ironik sahneler de mevcuttur. Örneğin yurttaki çocuklar kurşuna dizilmiş bazı kimselerin burunlarına karıncaların girip çıktıklarını gördükleri zaman olduğu gibi (Fortún, 1987, s. 63); ya da okuması yazması neredeyse hiç olmayan bir milis Celia'nın arkadaşlarından birinin evinde bir arama yaptığında, sırf evdekilerin monarşi yanlısı olduklarını kanıtladığını sandığı Bragenole Viskontu adında bir kitap buldu diye aile üyelerini tutuklamaya kalkması gibi (Fortun, 1987, s. 78).

"İyi aile"den gelen bir genç kızdan bütün bekleyebileceklerimize rağmen Celia, belli ölçüde bir kahramanlık ve gözü peklikle her şeye uyum sağlamıştır; aslında bu büyük bir olasılıkla hemen herkesin başına gelmiştir: yiyecek alabilmek için daha şafak sökmeden kuyruğa girer, otlar ya da fareler gibi ne bulursa onu yer (Fortún, 1987, s. 239) ve bulduklarını kendi yakınlarına paylaştırır, arkadaşlarına yardım edebilmek için bombaların altında sokaklarda koşuşturur (Fortún, 1987, s. 88-99), tanımadığı sığınmacıları kendi evine alır, v.s. Ancak manevi değerleri hâlâ ayaktadır ve hiç kimseyi 
asla ihbar etmez, kurşuna dizme olaylarını da "gerekli" bir şey olarak kabullenmez. Savaşın sonunun yaklaşmakta olduğunu gördüğünde, başlıca kaygısı ailesini ve ülkesini bekleyen belirsiz gelecek olur (Fortún, 1987, s. 205 ve 258). Yine de kolay yolu seçmeye yönelmez, pek çok başkalarının yapmaya başladıkları gibi saf değiştirmez (Fortún, 1987, s.300) ve savaş boyunca ideolojilerin ve çatışmaların dışında kalmış olmasına rağmen babasının izinden sürgüne doğru yola çıkar. İçini kaplayan tek duygu, Franco İspanya'sının kendisinin içinde yaşamış olduğu dünyayla hemen hemen hiçbir ilgisi olmayacağının bilincinde olarak, ülkesinin fiziksel ve manevi açıdan mahvolduğu duygusudur ve hepsini beklemekte olan o belirsiz göç, onu korkutmaktadır.

Sadece Valencia'daki son gününde Celia, o zamana kadar kendisine nezaketle davranmış olan kimselerin onu "düşman" olmakla suçlamaları karşısında bir an için öfkeye kapılır. İşte o zaman çevresindeki pek çok kişinin, hayatlarını tehlikeye atmamak için yalan söylediklerinin ve gerçek ideolojilerini gizlediklerinin farkına varır, ayrım gözetmeden yapılan kurşuna dizme olaylarının belki de pek o kadar isabetsiz olmadığını düşünür (Fortún, 1987, s. 288-289).

Celia, dizinin ilk kitaplarındaki o masum ve mutlu kız çocuk olmaktan çıkarak, hayatın sillesini yiyerek olgunlaşmış bir genç kıza dönüşmüş, ölümün, yalnızlığın ve açlı̆̆ın ortasında tek başına yaşamak zorunda kalmıştır (Campos, 2016, s.1). Dolayısıyla bu roman "genç kızlar için bir okuma parçası" olmadığı gibi bir çocuk kitabı da değildir; ne yazık ki halkın çok da ilgisini çekmemiş olmasına rağmen, büyük bir olasılıkla İspanya'daki iç savaş hakkında yazılmış en güzel eserlerden biridir. İnsanı en çok etkileyen yanı da savaşa son derece gerçekçi bir bakış açısıyla bakmasıdır, çünkü o yıllarda yazarlarının ideolojisine bağımlı kalarak, hiçbir farklılığ 1 ve ayrımı ortaya koymadan bir tarafı överken öteki tarafı karalama eğilimdeki öteki kitaplarla kıyaslandığında, Fortún'un eseri daha objektif bir bakış açısıyla olaylara dışarıdan bakan bir noktada durmaktadır. Yazarın kendisi kesinlikle Cumhuriyetçi kesime bağlı olduğu halde hiçbir tarafin militanı olmamıştır (Trapiello, 2016s. 11) ve fikirleri tanık olduğu şeylerin olumsuz yanlarını anlatmasına, yani korkuyu, kimsesizliği, zorunlu suskunluğu, kötü örgütlenmeyi, bombardımanları, sığınmacıları, yapılan eziyetleri, "gezintileri”, hiçbir adalet güvencesi verilmeden ve ayrım gözetmeden insanların kurşuna dizilmelerini, hızla artan yolsuzlukları, yiyecek kuyruklarındaki kavgaları, fırsat düşkünlüklerini, silahlı kişilerin yaptıklarının cezasız kalmasını, neredeyse çocuk yaştaki gençlerin askere alınmalarını v.s. göstermesine bir engel oluşturmamıştır.

Belki de hem Celia hem de yazdığı kitap taraf tutmadığı, Cumhuriyetçileri övmediği ve Franco yandaşlarına yeterince sövmediği için Fortún bu kitabın daha önce yayımlanmasını istememiştir. Eğer yayımlamış olsaydı, savaştan yenik çıkanların pek çoğu onu angaje olmamakla suçlayacak ve sürgündeki pek çok kişi büyük bir olasılıkla anlattı̆̆ kanlı sahnelerden (doğru olduklarını bile bile) rahatsız olacaklardı. Öte yandan Franco İspanyası bu unsurları kendi propagandası için kullanabilmiş olsaydı da, kitapta isyancılarla ilgili olarak yaratılan imaj da pek o kadar olumlu olmayacaktı (Trapiello, 2016, s. 14; Belmonte, 2013, s. 125). Kısacası ne galipler ne de mağluplar bu romanın gösterdiği realiteyi kabul etmeyi isteyeceklerdi; hiç de kurgusal olmayan, ama resmî 
tarih ve her iki tarafın övgü dolu anlatıları yüzünden gizli kalmış bir realiteydi bu.

Bu anlamda Celia Devrim Günlerinde, İspanya'daki İç Savaş hakkında tarafsız bir perspektifle yazılmış ilk romanlardan biridir. Dahası Fortún, çatışmalar sırasındaki kendi kişisel deneyimlerini anlatmak, hayatta kalabilmek için olgunlaşmaktan başka çareleri olmayan ve o yılları ömürleri boyunca hayatlarının en çarpıcı anları olarak daima hatırlayacak olan bütün bir çocuk ve gençlik kuşağının uğradığı değişimi anlatabilmek (Franco, 2013, s. 72) için (zaten alışık olduğu biçimde) çocuksu bir bakış açısı kullanmıştır.

\section{Notlar}

1 Öğretmen ve II. Cumhuriyet döneminde sosyalist milletvekili olan María de la O Lejárraga, eşi Gregorio Martínez Sierra'nın tiyatro eserinin gerçek yazarıydı ama işinde uyandırabileceği yankılar nedeniyle anonim kalmayı yeğlemişti. Madrid’te Elena Fortún ile eşinin müdavimleri oldukları aydın çevrenin içinde bulunuyordu. Ayrıca Fortún gibi o da Lyceum Club'un üyesiydi. 1926 yılında kadınlar arasında fikir alışverişini özendirmek ve sanatsal, yazınsal ve sosyal etkinlikleri geliştirmek amacıyla kurulmuş olan bu kulüp, 20'li ve 30'lu yıllarda kadın entellektüellerin temel direğini oluşturuyordu (daha fazla bilgi için Bkz. Marina ve Rodríguez de Castro, 2009). Daha sonra artık sürgündeyken çocuklar için bazı komik oyunlar yazarak, film yapılması düşüncesiyle Walt Disney’e gönderdi. Bunların hiçbiri kabul edilmediği halde, içlerinden bir tanesi (Viviana y la gata egoísta [Viviana ile bencil kedi]), Lady and the Tramp hikâyesiyle büyük benzerlik göstermektedir.

2 Resim bölümü öğretim üyesi ve Blanco y Negro'nun çalışanı olan Santiago Regidor, ayrıca Elena Fortún'un komşusu ve arkadaşıydı (Antón ve Molero, 2012, s. 3). Bu dizi kitap biçiminde yayımlanmaya başlayınca, resimleri yapan kişi, Celia'nın kıvırcık saçlı, kalın ayak bilekleri soket çoraplı, sürekli şaşkın bakışlı zayıf kız çocuğu biçimindeki klasik tipinin yaratıcısı olan Francisco Molina y Gallent oldu (Dorao, 1999: 23).

3 Bu kız yurdu 1915 yılında (daha başkalarının yanı sıra Lorca ve Buñuel'in de kaldıkları ünlü Residencia de Estudiantes (Öğrenci Yurdu) örnek alınarak), kızların yüksek öğrenim görmelerini desteklemek amaciyla kurulmuştu. Kı öğrencilere yatacak yer veriyor, laboratuvar ve kütüphane hizmetlerinden yararlanmalarını, ayrıca konferanslara, kurslara ve benzeri etkinliklere katılmalarına olanak sağlıyordu. Yurdun müdürü, 1936'da iç savaş başladığında kapanmasına kadar María de Maeztu'ydu.

4 Bu konuda danış1labilecek kaynak: Graig, Ian S. (1998) "La censura franquista en la literatura fantástica para niñas: Celia y Antoñita la Fantástica bajo el Caudillo", XIII. Uluslararası Hispanist Derneği Kongresi Tutanakları, Sanal Cervantes Merkezi, IV: 69-78. Çevrimiçi: (22.01.2018) https://cvc.cervantes.es/literatura/aih/pdf/13/aih_13_4_008.pdf.

5 O dönemde İspanya'da yetişkinlik yaşı 23'tür.

6 Zaten Celia devrim günlerinde, tam olarak Küçük anne Celia'nın sona erdiği gün başlamaktadır (Franco, 2013: 68).

7 Nuria Capdevilla-Argüelles'in, "Elena Fortún (1885-1952) y Celia. El Bildungsroman truncado de una escritora moderna" başl1klı makalesinde bunu böyle yorumladığı görülür (Lectora, 11, 2005: 263-280).

8 Bu sözcük, İspanyol iç savaşı sırasında, genellikle düzensiz gruplar tarafından ve geceleyin yapılan tutuklamalardan ve tutuklanan bu kişilerin öldürülmek üzere bir yerlere götürülmesinden söz ederken kullanılmıştır. 
9 Esirleri yasadışı bir şekilde tutmak, işkenceden geçirmek ve yargılamak için komünistler ve anarşistler tarafindan hapishane olarak kullanılan yerler.

1012 Ağustos 1936 günü gerçekleşen bu olayda, içinde Jaén'den ve Córdoba'dan (aralarında Jaén piskoposunun da bulunduğu) 254 "sağc1" mahpusun bulunduğu bir tren Alcalá de Henares hapishanesine doğru yol alırken Madrid yakınlarında küçük bir istasyona geldiğinde bir grup milis tarafından önü kesilir ve mahpuslardan 189'u kurşuna dizilir.

11 Eduardo López Ochoa (1877-1936), II. Cumhuriyet döneminde muhafazakâr hükümet tarafindan 1934 yılında çıkan Asturias madenci ayaklanmasını bastırmakla görevlendirilmiş subaylardan biriydi, bu nedenle de, General Yagüe gibi daha başka subaylara kıyasla, harekâtta oldukça ölçülü davranmasına rağmen nefret edilen bir kişiye dönüşmüştü. Madrid’te Carabanchel hastanesinde geçirdiği bir ameliyattan sonra nekahet döneminde olduğundan, iç savaşı başlatan ayaklanmaya katılmadı. Yine de bir ay sonra katledilmekten kurtulamadı.

12 1909'da doğup 2002'de ölen Isabel García Lorca, şair Federico García Lorca'nın küçük kız kardeşiydi. Yazar ve öğretim üyesi olarak hayatının büyük bir kısmını ağabeyinin eserlerini düzenlemeye ve tanıtmaya adamıştı.

13 Laura de los Ríos y Giner (1913-1981) II. Cumhuriyet döneminde Millî Eğitim Bakanı olan Fernando de los Ríos ile Institución Libre de Enseñanza (Serbest Eğitim Enstitüsü)'nün yaratıcısının yeğenlerinden birinin kızıydı. ABD'deki sürgün yıllarında İspanyol Dili ve Edebiyatında doktorluk unvanına sahip olarak önde gelen akademisyenlerden biriydi. García Lorca ailesinin yakın çevresinde bulunmaktaydı ve Isabel'in çok yakın arkadaşıdı, sonradan onun yine yazar olan bir başka ağabeyi ile evlendi. Savaş onu Isabel'le birlikte Madrid'teki Residencia de Señoritas'da yakalamış, ilk aylar boyunca çocuklar için yurtlar organize etmeye yardımcı olmuş ve dersler vermişti.

14 Manuel Aguilar Muñoz (1888-1965) 1986'da kapanana kadar İspanya'nın en önemli yayınevlerinden biri olan Aguilar yayınevini 1923'te kurmuştu.

15 Ramiro de Maeztu (1874-1936), monarşik ideoloji yanlısı ve gerici bir yazar ve diplomatken savaşın başlarında birkaç milis tarafından tutuklanmış ve 1936'nın Ekim ayındaki kargaşada kurşuna dizilmişti. Pedro Muñoz Seca (1879-1936) yine önemli bir tiyatro yazarıydı, Cumhuriyet karşıtı ve Katolik olmakla suçlanarak 1936'nın Kasım ayında tutuklanıp kurşuna dizildi.

\section{Kaynaklar}

Antón Cabello, Ma del Mar ve José Antonio Molero (2012). "Personajes en su historia. Elena Fortún. Madrid, 1886-1952”, Gibralfaro, 77: 1-10.

Belmonte, José (2013). "El peso y la sombra de la guerra civil Española en la narrativa para jóvenes", Ocnos, 9: 121-139.

Bravo-Villasante, Carmen (1986). "Elena Fortún y los libros de Celia. Datos sobre su vida y su obra”. Bravo-Villasante, Carmen ve d. (Haz.) Elena Fortún (1886-1952), Madrid, Asociación Española de Amigos del IBBY: 7-20.

Dorao, Marisol (1987). “Estudio introductorio”. Fortún, Elena (1987) Celia en la revolución, Madrid, Aguilar: 9-14.

Dorao, Marisol (1990). "Elena Fortún y Celia", CLIJ, 19 (3): 22-26.

Dorao, Marisol (1999). Los mil sueños de Elena Fortún, Cádiz: Cádiz Üniversitesi.

Fortún, Elena (1939). Celia madrecita, Madrid: Aguilar.

Fortún, Elena (1946). "El arte de contar cuentos a los niños”, Educación y Biblioteca, 123, 2001: 21-27.

Fortún, Elena (1987). Celia en la revolución, Madrid: Aguilar. 
Franco, Marie (2013). “Les livres absents d'Elena Fortún: écrire la guerre civile dans les années 40", Enfants en temps de guerre et littératures de jeneusse (20-21e siècles), Ekim: 65-73.

García Padrino, Jaime (1986). "El mundo literario de Elena Fortún”. Bravo-Villasante, Carmen ve d. (Haz.) Elena Fortún (1886-1952), Madrid, Asociación Española de Amigos del IBBY: 31-54.

Marina, José Antonio ve Ma Teresa Rodríguez de Castro (2009). La conspiración de las lectoras, Barcelona: Anagrama.

Martín Gaite, Carmen (1993). "Prólogo". Fortún, Elena (1933) Celia, lo que dice, Madrid, Alianza: 7-44.

Sotomayor, $\mathrm{M}^{\mathrm{a}}$ Victoria (2008). "La mirada adolescente de Celia en la revolución de Elena Fortún”. Roig Rechou, Blanca-Ana ve d. (Haz.) A Guerra Civil Española na narrativa infantil e xuvenil, Vigo, Xerais: 271-281.

Trapiello, Andrés (2016). "Prólogo". Fortún, Elena (1987) Celia en la revolución, Sevilla, Renacimiento: 7-20.

\section{Elektronik kaynaklar}

Blas Ruiz, Ma José (2013). “Elena Fortún y la Editorial Aguilar”, Antigua editorial Aguilar, S. y. Çevrimiçi: (20.07.2016) https://antiguaeditorialaguilar. wordpress.com/2013/07/18/ elena-fortun-y-la-editorial-aguilar/

Campos Cacho, Sergio (2016) "La inocencia bajo las bombas", Revista de Libros: 1-4. Çevrimiçi:(20.11.2017) http://www.rev_stadel_bros.com/art_culo_mpr_m_ble. php?art $=1598 \& \mathrm{t}=$ blogs 